\title{
A Study on Footprint Dimensions Between Sports and Non-Sports Category in Mangaluru Students Population
}

Pooja V Menon*, BhavyaShree Rai and Sanjay R

Department of Criminology and Forensic Science, School of Social Work, India

\begin{abstract}
Foot Print evidence is a type of circumstantial evidence mainly found at outdoor crime scene that can link a perpetrator to a crime. The valid foot print impression is based on the fact that it differs from person to person. A foot print taken in a controlled environment and a foot print at the scene of crime cannot be easily compared. Since crime scene prints are hardly ever complete, experts are then given the task of matching a partial footprint to one that is taken in a control environment. Most of the matching is done in order to compare and existing foot print to a partial print found at the crime scene is based on guess work. In case of sports persons, as they play, the footprint dimensions may change compared to non-sports. To check that difference on dimensions we have conducted this study. The study can help investigating officer to shortlist the suspects by comparing the footprint dimensions.
\end{abstract}

Keywords: Footprint dimensions; Crime scene; Suspects

\section{Introduction}

Footprints are the images or the impressions left behind by a person walking or running. Hoof prints and paw prints are those left by animals with hooves or paws rather than feet, while shoeprints are the specific term for prints made by shoes. They may be indentations in the ground or something placed on to the surface that was stuck to the bottom of the foot. A track way is a set of footprints in soft earth left by human or animals. Footprints can be followed while tracking during a hunt or can provide evidence of other activities. Some footprints remain unexplained, for other several factors [1].

The print left behind at a crime scene gives important evidence to the perpetrator of the crime. Shoes may have different prints based on the sole design and the wear that it has received this helps to identify the suspects. Photographs or castings of footprints can be taken to preserve the finding. Analysis of footprints and shoeprints is important in forensic science [2].

The methods used to collect foot prints include photography, tracing, lifting and casting. All prints and impressions should be photographed before attempting any other method. While taking the photographs keep the lens of the camera parallel to the surface on which the print is found. Set the shutter at the smallest permissible f-stop in order to obtain the greatest depth of the field. A lash should be used even in sun light so the details are clearly defined. Place a ruler along the length of the print. Identification details such as date, case number signature of the investigator, the witnesses may be written on a piece of paper and placed near by the print. [2]

\section{Materials Required}

- Color powder(red)

- Water

- $\quad$ Plastic plate

- $\quad$ A3 White paper sheets

- Measuring scale and protractor

- Writing materials

\section{Methodology}

The study population consisted of 50 Non sports persons and
50 sports persons belonging to a random student population in Mangaluru City, Dakshina Kannada district from the age group of 1825 years. Footprints were collected from them using red powder, and the total number of prints obtained and their varied dimensions were statistically represented. All Samples were collected on voluntary Basis. Consent form was issued.

The following parameters were considered:

- $\quad$ Foot Length

- Foot Breadth

- Foot Angle

\section{Foot length}

The distance between the second toe to the heel of the foot.

\section{Foot breadth}

The maximum horizontal breadth, wherever found, across the foot perpendicular to the long axis.

\section{Foot angle}

The angle between second toe and the ball of the foot.

\section{Objectives and Procedure}

To determine whether there is a difference between the footprint dimensions among Sports and Non-Sports persons. After issuing a consent form the Researchers requested the subjects to clean their legs and later started to record the Footprints. The footprint was obtained

*Corresponding author: Pooja $\mathrm{V}$ Menon, Department of Criminology and Forensic Science, School of Social Work, India, Tel: 7338532763; E-mail: poojamenon2796@gmail.com

Received July 31, 2018; Accepted August 31, 2018; Published September 19, 2018

Citation: Menon PV, Rai B, Sanjay R (2018) A Study on Footprint Dimensions Between Sports and Non-Sports Category in Mangaluru Students Population. J Forensic Res 9: 427. doi:10.4172/2157-7145.1000427

Copyright: (c) 2018 Menon PV, et al. This is an open-access article distributed under the terms of the Creative Commons Attribution License, which permits unrestricted use, distribution, and reproduction in any medium, provided the original author and source are credited. 
Page 2 of 5

by making the subjects to place their feet on the red paste obtained by mixing red powder in water and immediately made them to place their feet on A3 sheet and was eventually pressed. Then the subjects were asked to clean their legs. After drying the prints, the prints were measured by using the scale and protractor foot length, breadth and foot angle (Figure 1).

\section{Profiling}

\section{Height and foot length}

From Table 1 it can be observed that out of 50, the maximum number of impressions (28) whose height falls between 169-178 $\mathrm{cm}$ out of which 10 prints are of length $23.2-24.2 \mathrm{~cm}$ and minimum 6 impressions whose height falls between $149-158 \mathrm{~cm}$ and their foot length is between $24.2-26.2 \mathrm{~cm}$.

Out of 50 impressions maximum number of foot length impression is 18 whose Foot length is between $23.2-24.2 \mathrm{~cm}$ and minimum is between $20.2-22.2 \mathrm{~cm}$.

From Table 2 it can be observed that out of 50, the maximum number of impressions (22) whose height falls between $169-178 \mathrm{~cm}$ in which 9 prints are of length $24.2-25.2 \mathrm{~cm}$ and minimum is 8 impressions whose height falls between $159-168 \mathrm{~cm}$ and their foot length is between $22.2-26.2 \mathrm{~cm}$.

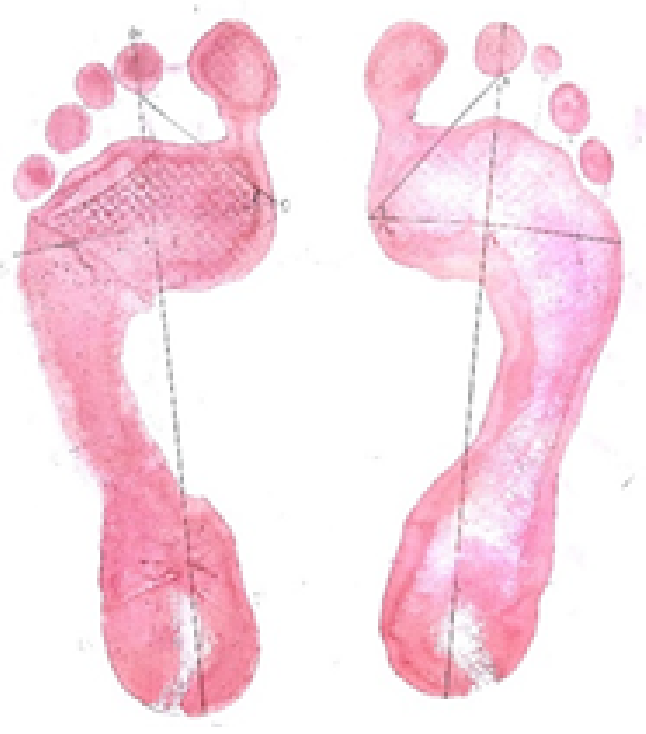

Figure 1: Procedure of collection of footprints.

\begin{tabular}{|c|c|c|c|c|c|}
\hline $\begin{array}{c}\text { HEIGHT (CM) } \\
\text { FOOT LENGTH } \\
\text { (CM) }\end{array}$ & $149-158$ & $\mathbf{1 5 9 - 1 6 8}$ & $\mathbf{1 6 9 - 1 7 8}$ & $\mathbf{1 7 9 - 1 8 8}$ & $\begin{array}{c}\text { GRAND } \\
\text { TOTAL }\end{array}$ \\
\hline $20.2-21.2$ & - & - & 1 & - & 1 \\
\hline $21.2-22.2$ & - & - & 1 & - & 1 \\
\hline $22.2-23.2$ & - & 3 & - & - & 3 \\
\hline $23.2-24.2$ & 4 & 2 & 10 & 2 & 18 \\
\hline $24.2-25.2$ & 1 & 2 & 6 & 1 & 10 \\
\hline $25.2-26.2$ & 1 & 1 & 6 & 5 & 13 \\
\hline $26.2-27.2$ & - & - & 2 & - & 2 \\
\hline $27.2-28.2$ & - & - & 2 & - & 2 \\
\hline GRAND TOTAL & 6 & 8 & 28 & 8 & 50 \\
\hline
\end{tabular}

\begin{tabular}{|c|c|c|c|c|}
\hline HEIGHT (CM) & $\mathbf{1 5 9 - 1 6 8}$ & $\mathbf{1 6 9 - 1 7 8}$ & $\mathbf{1 7 9 - 1 8 8}$ & $\begin{array}{c}\text { GRAND } \\
\text { TOTAL }\end{array}$ \\
\hline FOOT LENGTH (CM) & & & & \\
\hline $22.2-23.2$ & 2 & - & - & 2 \\
\hline $23.2-24.2$ & 2 & 4 & - & 6 \\
\hline $24.2-25.2$ & 2 & 9 & 3 & 14 \\
\hline $25.2-26.2$ & 2 & 6 & 9 & 17 \\
\hline $26.2-27.2$ & - & 3 & 5 & 8 \\
\hline $27.2-28.2$ & - & - & 3 & 3 \\
\hline GRAND TOTAL & 8 & 22 & 20 & 50 \\
\hline
\end{tabular}

Out of 50 impressions maximum number of foot length impression is 17 whose Foot length is between $25.2-26.2 \mathrm{~cm}$ and minimum is between $22.2-23.2 \mathrm{~cm}$.

From Table 3 it can be observed that out of 50, the maximum number of impressions (30) whose height falls between $149-158 \mathrm{~cm}$ in which 15 prints are of length $22.2-23.2 \mathrm{~cm}$ and minimum is 10 impressions whose height falls between $159-178 \mathrm{~cm}$ and their foot length is between $22.2-24.2 \mathrm{~cm}$.

Out of 50 impressions maximum number of foot length impression is 23 whose Foot length is between $22.2-23.2 \mathrm{~cm}$ and minimum is between $24.2-26.2 \mathrm{~cm}$.

From Table 4 it can be observed that out of 50, the maximum number of impressions (22) whose height falls between 149-158 $\mathrm{cm}$ in which 8 prints are of length $21.2-22.2 \mathrm{~cm}$ and minimum is 10 impressions whose height falls between $169-178 \mathrm{~cm}$ and their foot length is between $23.2-24.2 \mathrm{~cm}$.

Out of 50 impressions maximum number of foot length impression is 12 whose Foot length is between $22.2-23.2 \mathrm{~cm}$ and $24.2-25.2 \mathrm{~cm}$ respectively and minimum is between $25.2-26.2 \mathrm{~cm}$.

\section{Height and foot breadth}

From Table 5 it can be observed that out of 50, the maximum number of impressions (28) whose height falls between 169-178 $\mathrm{cm}$ in which 17 prints are of breadth $9.2-10.2 \mathrm{~cm}$ and minimum is 6 impressions whose height falls between $149-158 \mathrm{~cm}$ and their foot breadth is between $9.2-10.2 \mathrm{~cm}$.

Out of 50 impressions maximum number of foot breadth impression is 28 whose Foot breadth is between $9.2-10.2 \mathrm{~cm}$ and minimum is between $8.2-9.2 \mathrm{~cm}$.

From Table 6 it can be observed that out of 50, the maximum number of impressions (22) whose height falls between 169-178 $\mathrm{cm}$ in which 11 prints are of breadth $9.2-10.2 \mathrm{~cm}$ and minimum is 8 impressions whose height falls between $159-168 \mathrm{~cm}$ and their foot breadth is between $8.2-10.2 \mathrm{~cm}$.

Out of 50 impressions maximum number of foot breadth impression is 23 whose Foot breadth is between $9.2-10.2 \mathrm{~cm}$ and minimum is between $8.2-9.2 \mathrm{~cm}$.

From Table 7 it can be observed that out of 50, the maximum number of impressions (30) whose height falls between 149-158 $\mathrm{cm}$ in which 21 prints are of breadth $8.2-9.2 \mathrm{~cm}$ and minimum is 20 impressions whose height falls between $159-178 \mathrm{~cm}$ and their foot breadth is between $8.2-9.2 \mathrm{~cm}$.

Out of 50 impressions maximum number of foot breadth impression is 31 whose Foot breadth is between $8.2-9.2 \mathrm{~cm}$ and minimum is 
Page 3 of 5

\begin{tabular}{|c|c|c|c|c|}
\hline HEIGHT (CM) & $\mathbf{1 4 9 - 1 5 8}$ & $\mathbf{1 5 9 - 1 6 8}$ & $\mathbf{1 6 9 - 1 7 8}$ & $\begin{array}{c}\text { GRAND } \\
\text { TOTAL }\end{array}$ \\
\hline FOOT LENGTH (CM) & & & & \\
\hline $20.2-21.2$ & 1 & - & - & 1 \\
\hline $21.2-22.2$ & 12 & - & - & 12 \\
\hline $22.2-23.2$ & 15 & 5 & 3 & $\mathbf{2 3}$ \\
\hline $23.2-24.2$ & 2 & 5 & 3 & 10 \\
\hline $24.2-25.2$ & - & - & 2 & 2 \\
\hline $25.2-26.2$ & - & - & 2 & 2 \\
\hline GRAND TOTAL & 30 & 10 & 10 & 50 \\
\hline
\end{tabular}

Table 3: Non-sports-female.

\begin{tabular}{|c|c|c|c|c|}
\hline HEIGHT (CM) & $\mathbf{1 4 9 - 1 5 8}$ & $\mathbf{1 5 9 - 1 6 8}$ & $\mathbf{1 6 9 - 1 7 8}$ & $\begin{array}{c}\text { GRAND } \\
\text { TOTAL }\end{array}$ \\
\hline FOOT LENGTH (CM) & & & & \\
\hline $20.2-21.2$ & 4 & - & - & 4 \\
\hline $21.2-22.2$ & 8 & 1 & - & 9 \\
\hline $22.2-23.2$ & 6 & 5 & 1 & 12 \\
\hline $23.2-24.2$ & 2 & 3 & 5 & 10 \\
\hline $24.2-25.2$ & 1 & 7 & 4 & 12 \\
\hline $25.2-26.2$ & 1 & 2 & - & 3 \\
\hline GRAND TOTAL & 22 & 18 & 10 & 50 \\
\hline
\end{tabular}

Table 4: Sports-female.

\begin{tabular}{|c|c|c|c|c|c|}
\hline $\begin{array}{c}\text { HEIGHT (CM) } \\
\begin{array}{c}\text { FOOT } \\
\text { BREADTH } \\
\text { (CM) }\end{array}\end{array}$ & $\mathbf{1 4 9 - 1 5 8}$ & $\mathbf{1 5 9 - 1 6 8}$ & $\mathbf{1 6 9 - 1 7 8}$ & $\mathbf{1 7 9 - 1 8 8}$ & Grand Total \\
\hline $8.2-9.2$ & 1 & 2 & 4 & - & 7 \\
\hline $9.2-10.2$ & 3 & 3 & 17 & 5 & 28 \\
\hline $10.2-11.2$ & 2 & 3 & 7 & 3 & 15 \\
\hline Grand Total & 6 & 8 & 28 & 8 & 50 \\
\hline
\end{tabular}

Table 5: Non-sports-male.

\begin{tabular}{|c|c|c|c|c|}
\hline HEIGHT (CM) & $\mathbf{1 5 9 - 1 6 8}$ & $\mathbf{1 6 9 - 1 7 8}$ & $\mathbf{1 7 9 - 1 8 8}$ & Grand Total \\
\hline FOOT BREADTH (CM) & & & & \\
\hline $8.2-9.2$ & 3 & 2 & - & 5 \\
\hline $9.2-10.2$ & 3 & 11 & 9 & 23 \\
\hline $10.2-11.2$ & 2 & 9 & 11 & 22 \\
\hline Grand Total & 8 & 22 & 20 & 50 \\
\hline
\end{tabular}

Table 6: Sports-male.

\begin{tabular}{|c|c|c|c|c|}
\hline HEIGHT (CM) & $\mathbf{1 4 9 - 1 5 8}$ & $\mathbf{1 5 9 - 1 6 8}$ & $\mathbf{1 6 9 - 1 7 8}$ & Grand Total \\
\hline FOOT BREADTH (CM) & & & & \\
\hline $7.2-8.2$ & 4 & - & 3 & 7 \\
\hline $8.2-9.2$ & 21 & 7 & 3 & 31 \\
\hline $9.2-10.2$ & 5 & 3 & 4 & 12 \\
\hline Grand Total & 30 & 10 & 10 & 50 \\
\hline \multicolumn{5}{|c}{ Table 7: Non-sports-female. } \\
\end{tabular}

between $7.2-8.2 \mathrm{~cm}$.

From Table 8 it can be observed that out of 50, the maximum number of impressions (22) whose height falls between 149-158 $\mathrm{cm}$ in which 18 prints are of breadth $8.2-9.2 \mathrm{~cm}$ and minimum is 10 impressions whose height falls between $169-178 \mathrm{~cm}$ and their foot breadth is between $9.2-10.2 \mathrm{~cm}$.

\begin{tabular}{|c|c|c|c|c|}
\hline HEIGHT (CM) & $\mathbf{1 4 9 - 1 5 8}$ & $\mathbf{1 5 9 - 1 6 8}$ & $\mathbf{1 6 9 - 1 7 8}$ & Grand Total \\
\hline $\begin{array}{c}\text { FOOT BREADTH } \\
\text { (CM) }\end{array}$ & & - & & \\
\hline $7.2-8.2$ & 18 & 2 & 2 & 1 \\
\hline $8.2-9.2$ & 4 & 13 & 6 & 22 \\
\hline $9.2-10.2$ & - & 2 & 2 & 4 \\
\hline $10.2-11.2$ & 22 & 18 & 10 & 50 \\
\hline Grand Total & \multicolumn{4}{c}{ Table 8: Sports-female. } \\
\hline
\end{tabular}

\begin{tabular}{|c|c|c|c|c|c|}
\hline HEIGHT (CM) & $\mathbf{1 4 9 - 1 5 8}$ & $\mathbf{1 5 9 - 1 6 8}$ & $\mathbf{1 6 9 - 1 7 8}$ & $\mathbf{1 7 9 - 1 8 8}$ & Grand Total \\
\hline $\begin{array}{c}\text { FOOT ANGLE } \\
\left({ }^{\circ}\right)\end{array}$ & & & & & \\
\hline $51-53$ & - & - & 3 & - & 3 \\
\hline $54-56$ & - & 1 & 4 & - & 5 \\
\hline $57-59$ & - & 1 & - & 1 & 2 \\
\hline $60-62$ & 4 & 4 & 8 & - & 16 \\
\hline $63-65$ & - & 1 & 4 & 3 & 8 \\
\hline $66-68$ & - & 1 & 4 & 3 & 8 \\
\hline $69-71$ & 2 & - & 3 & 1 & 6 \\
\hline $72-74$ & - & - & 2 & - & 2 \\
\hline Grand Total & 6 & 8 & 28 & 8 & 50 \\
\hline
\end{tabular}

Out of 50 impressions maximum number of foot breadth impression is 23 whose Foot breadth is between $9.2-10.2 \mathrm{~cm}$ and minimum is between $7.2-8.2 \mathrm{~cm}$.

\section{Height and foot angle}

From Table 9 it can be observed that out of 50, the maximum number of impressions (28) whose height falls between $169-178 \mathrm{~cm}$ in which 8 prints are of foot angle $60^{\circ}-62^{\circ}$ and minimum is 6 impressions whose height falls between $149-158 \mathrm{~cm}$ and their foot angle is between $60^{\circ}-62^{\circ}$.

Out of 50 impressions maximum number of foot angle impressions are 16 who's Foot angle is between $60^{\circ}-62^{\circ}$ and minimum is between $57^{\circ}-59^{\circ}$ and $72^{\circ}-74^{\circ}$ respectively.

From Table 10 it can be observed that out of 50, the maximum number of impressions (22) whose height falls between $169-178 \mathrm{~cm}$ in which 8 prints are of foot angle $63^{\circ}-65^{\circ}$ and minimum is 8 impressions whose height falls between $159-168 \mathrm{~cm}$ and their foot angle is between $54^{\circ}-56^{\circ}$.

Out of 50 impressions maximum number of foot angle impressions is 13 who's Foot angle is between $66^{\circ}-68^{\circ}$ and minimum is between $72^{\circ}-74^{\circ}$.

From Table 11 it can be observed that out of 50, the maximum number of impressions (30) whose height falls between $149-158 \mathrm{~cm}$ in which 8 prints are of foot angle $63^{\circ}-65^{\circ}$ and minimum is 20 impressions whose height falls between $159-178 \mathrm{~cm}$ and their foot angle is between $60^{\circ}-62^{\circ}$.

Out of 50 impressions maximum number of foot angle impressions is 13 who's Foot angle is between $60^{\circ}-62^{\circ}$ and minimum is between $72^{\circ}-74^{\circ}$.

From Table 12 it can be observed that out of 50, the maximum number of impressions (22) whose height falls between $149-158 \mathrm{~cm}$ in which 5 prints are of foot angle $51^{\circ}-53^{\circ}$ and minimum is 10 impressions whose height falls between $169-178 \mathrm{~cm}$ and their foot angle is between $63^{\circ}-65^{\circ}$. 


\begin{tabular}{|c|c|c|c|c|}
\hline HEIGHT (CM) & $\mathbf{1 5 9 - 1 6 8}$ & $\mathbf{1 6 9 - 1 7 8}$ & $\mathbf{1 7 9 - 1 8 8}$ & Grand Total \\
\hline FOOT ANGLE $\mathbf{(}^{\circ}$ ) & & & & \\
\hline $51-53$ & 1 & 1 & - & 2 \\
\hline $54-56$ & 3 & - & 1 & 4 \\
\hline $57-59$ & 2 & 2 & 4 & 8 \\
\hline $60-62$ & 1 & 3 & 3 & 7 \\
\hline $63-65$ & - & 8 & 4 & 12 \\
\hline $66-68$ & 1 & 6 & 6 & 13 \\
\hline $69-71$ & - & 2 & 1 & 1 \\
\hline $72-74$ & - & - & 1 & 50 \\
\hline Grand Total & 8 & 22 & 20 & \\
\hline & & & & \\
\hline
\end{tabular}

Table 10: Sports-male.

\begin{tabular}{|c|c|c|c|c|}
\hline HEIGHT (CM) & $\mathbf{1 4 9 - 1 5 8}$ & $\mathbf{1 5 9 - 1 6 8}$ & $\mathbf{1 6 9 - 1 7 8}$ & Grand Total \\
\hline FOOT ANGLE $\mathbf{(}^{\circ}$ ) & & & & \\
\hline $51-53$ & 3 & 1 & - & 4 \\
\hline $54-56$ & 5 & 1 & 1 & 7 \\
\hline $57-59$ & 4 & 2 & 1 & 7 \\
\hline $60-62$ & 7 & 4 & 2 & 13 \\
\hline $63-65$ & 8 & 2 & 1 & 11 \\
\hline $66-68$ & 1 & - & 2 & 3 \\
\hline $69-71$ & 2 & - & 2 & 1 \\
\hline $72-74$ & - & - & 1 & 50 \\
\hline Grand Total & 30 & 10 & 10 & 4 \\
\hline
\end{tabular}

Table 11: Non-sports-female.

\begin{tabular}{|c|c|c|c|c|}
\hline HEIGHT (CM) & $\mathbf{1 4 9 - 1 5 8}$ & $\mathbf{1 5 9 - 1 6 8}$ & $\mathbf{1 6 9 - 1 7 8}$ & Grand Total \\
\hline FOOT ANGLE ( & & & & \\
\hline $51-53$ & 5 & 1 & - & 6 \\
\hline $54-56$ & 4 & 5 & 1 & 10 \\
\hline $57-59$ & 4 & 4 & 2 & 10 \\
\hline $60-62$ & 3 & 2 & - & 5 \\
\hline $63-65$ & 3 & 2 & 4 & 9 \\
\hline $66-68$ & 2 & 3 & 1 & 6 \\
\hline $69-71$ & - & 1 & 1 & 2 \\
\hline $72-74$ & - & - & 1 & 1 \\
\hline $75-77$ & 1 & - & - & 1 \\
\hline Grand Total & 22 & 18 & 10 & 50 \\
\hline
\end{tabular}

Out of 50 impressions maximum number of foot angle impressions is 20 who's Foot angle is between $54^{\circ}-59^{\circ}$ and minimum is between $72^{\circ}-77^{\circ}$.

\section{Analysis and Results}

\section{Comparison between non-sports and sports persons}

Left foot-males: Figure 2 represents the comparison of footprint length, breadth, $\theta$ between non-sports and sports person in left leg of males. From the above graph it can be observed that there is a significant difference of $1 \mathrm{~cm}$ in Length and also a minute difference in angle between Non-Sports and Sports person.

Right foot-males: Figure 3 represents the comparison of foot print

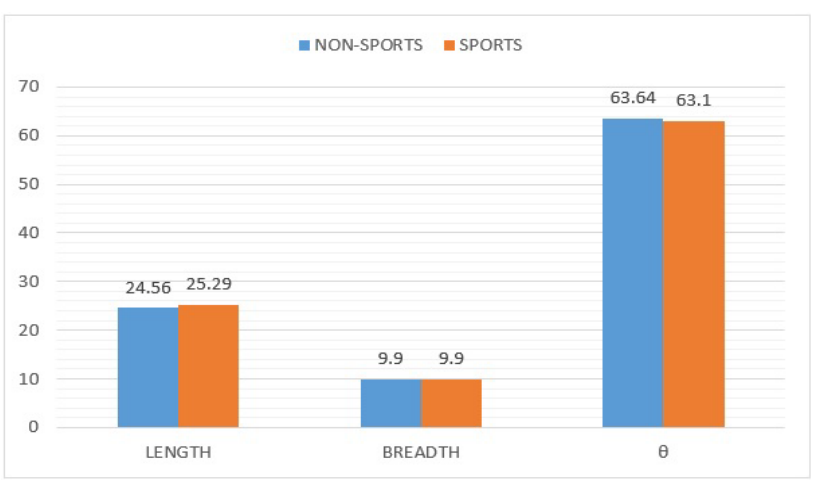

Figure 2: Comparison in left foot-males.

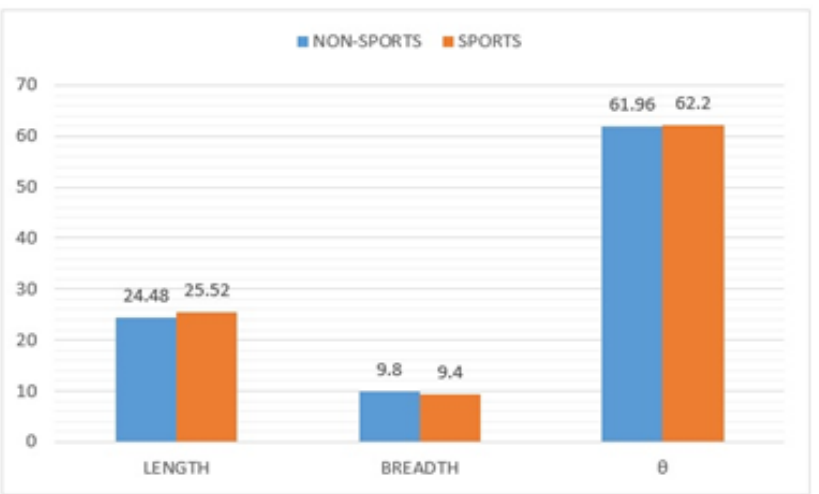

Figure 3: Comparison in right foot-males.

length, breadth, $\theta$ between non-sports and sports person in right leg of males. From the graph it can be observed that there is a significant difference of $1 \mathrm{~cm}$ length and also $1^{\circ}$ difference in angle between nonsports and sports person.

Left foot-females: Figure 4 represents the comparison of footprint length, breadth, $\theta$ between non-sports and sports person in left leg of females. From the graph it can be observed that there is a significant difference of $1 \mathrm{~cm}$ length and breadth and also a $1^{\circ}$ difference in angle between non-sports and sports persons.

Right foot-females: Figure 5 represents the comparison of footprints length, breadth, $\theta$ between non-sports and sports person in right leg of females. From the bar graph it is observed that there is a significant difference of $1 \mathrm{~cm}$ length and $4 \mathrm{~cm}$ difference in breadth and also a $2^{\circ}$ difference angle between non-sports and sports persons.

\section{Comparison graph between non-sports and sports}

The length and angle difference exist between non-sports and sports person in males while all length, breadth, angle difference exist in females (Figure 6).

\section{Results}

\section{On Comparison between non-sports and sports}

In male-left, there is a length difference of $0.7 \mathrm{~cm}$ and $0.5^{\circ}$ difference in angle.

In male-right, there is a length difference of $1.1 \mathrm{~cm}, 0.4 \mathrm{~cm}$ difference in breadth, $0.3^{\circ}$ difference in angle. 


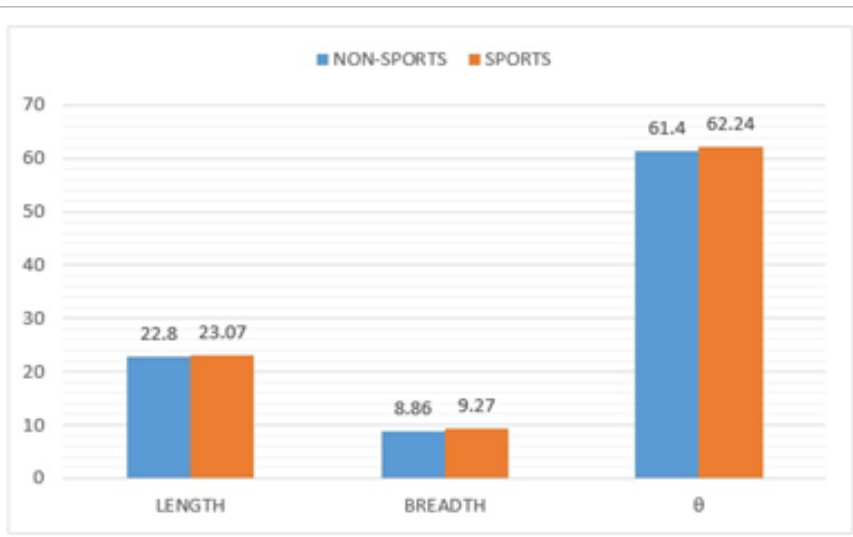

Figure 4: Comparison in left foot-females.

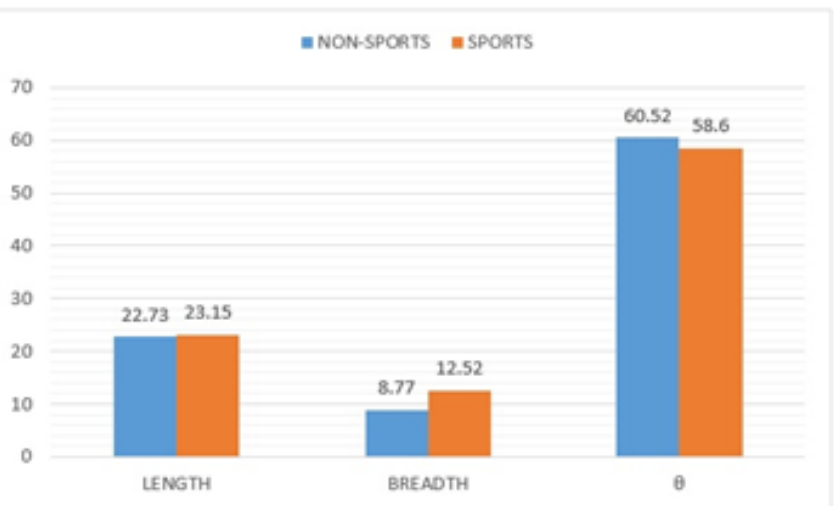

Figure 5: Comparison in right foot-females.

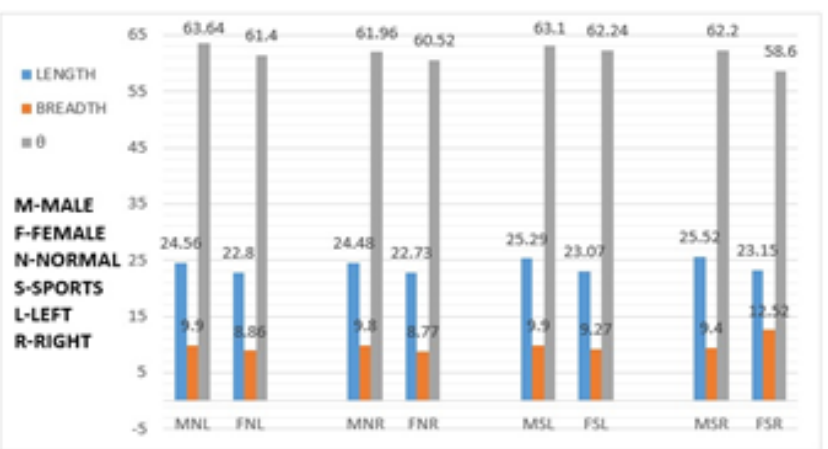

Figure 6: Comparison of length, breadth and angle.
In female-left, there is a length difference of $0.2 \mathrm{~cm}$ and $0.4 \mathrm{~cm}$ difference in breadth, $0.8^{\circ}$ difference in angle.

In female-right, there is a difference of $0.4 \mathrm{~cm}$ length and $3.8 \mathrm{~cm}$ difference in breadth and also a $2^{\circ}$ difference in angle.

\section{Discussion}

The study reveals that there exists only a minute difference between non-sports and sports person in footprint dimensions. The study was limited to Mangaluru city. Since the researchers are students both time and finance constrains existed. Specific sports categories could be included and can increase the sample size on the availability of the sports persons. More Parameters could be included for further study. Gait pattern analysis could be also be done for further studies other than measurements.

\section{Conclusion}

The study is on footprint dimensions between sports and nonsports persons [3-7]. The study shows there is no much difference in Footprint dimensions among sports and non-sports persons.

\section{References}

1. Footprint-Wikipedia.

2. Nabar BS (2002) Forensic Science in crime investigation. Asia Law House, India

3. Hyeyoung K (2013) A comparison of the foot and ankle condition between elite athletes and non-athletes. J Phys Ther Sci 25:1269-1272.

4. Lessby $G$ ( 2011). Sport influence on footprints of colombian's powerlifters. Portuguese J of Sport Sci 11: 1015-1017.

5. Ronna (2012) Leg length differences affecting athletic performance and physical well being, Proactive Magazine, India

6. Rosenbaum SH (1994) Effects of walking speed on plantar pressure and hindfoot angular motion. Gait and Posture 2: 191-197.

7. Kulthanan T (2004) A study of footprints in athletes and non-athletic people. J Med Assoc Thai 87: 788-793. 